\title{
EFEKTIVITAS PERATURAN MENTERI TENAGA KERJA NO.39 TAHUN 2016 TENTANG PENEMPATAN TENAGA KERJA DI KOTA MALANG
}

\author{
THE EFFECTIVENESS OF THE MINISTER OF MANPOWER \\ REGULATION NUMBER 39 OF 2016 CONCERNING LABOR \\ PLACEMENT IN MALANG CITY
}

\author{
Siti Awaliyah \\ JurusanHukum dan KewarganegaraanUniversitas Negeri Malang \\ Jl Semarang No.5 Malang \\ Email:siti.awaliyah.fis@um.ac.id
}

\begin{abstract}
The purpose of this article is to discuss the mechanism of employment according to Minister of Manpower Regulation No.39 of 2016, work placement procedures in Malang City, and conformity between the implementation of recruitment of workers and their implementation. The study used a socio-legal approach with primary data sources from the Manpower Office staff and secondary data sources from the Minister of Manpower Regulation No.39 of 2016 concerning labor placement. Data collection with interviews and document studies. The mechanism of placement of workers based on Minister of Manpower Regulation No. 39 of 2016 involves 3 agencies, namely Disnaker, companies, and Private Workforce Training Institutions. Job seekers apply for job search cards (AK/I) to the Manpower Office. The Manpower Office issues AK/I cards and records job seekers on AK/II cards. The employer submits a workforce application by submitting an AK/III card. Disnaker delivers job seekers to employers to take part in the selection. The implementation of employment in the city of Malang is in accordance with the provisions of Minister of Manpower Regulation No. 39 of 2019. Constraints faced are transportation costs for officers and companies not reporting labor requirements to the Manpower Office.
\end{abstract}

Keywords: Placement of Workers, JobSeekers, Interagency Workers

\begin{abstract}
Abstrak
Tujuan penulisan artikel untuk membahas mekanisme penempatan tenaga kerja menurut Peraturan Menteri Tenaga Kerja No.39 tahun 2016, prosedur penempatan kerja di Kota Malang, dan kesesuaian antara pelaksanaan perekrutan tenaga kerja dengan pelaksanaannya. Kajian menggunakan pendekatan sociolegal dengan sumber data primer daripegawaiDinas Tenaga Kerja dan sumber data sekunder dari Peraturan Menteri Tenaga Kerja No.39 tahun 2016. Pengumpulan data denganwawancara dan studi dokumen. Mekanisme penempatan tenaga kerja berdasarkan Permenaker No.39 Tahun 2016 melibatkan 3 instansi, yaituDisnaker, perusahaan, dan Lembaga Pelatihan Tenaga KerjaSwasta. Pencari kerja mengajukan permohonan kartu pencari kerja (AK/I) keDinas Tenaga kerja. Dinas Tenaga Kerja menerbitkan kartu AK/I dan mendata pencari kerja dalam kartu AK/II. Pemberi kerja mengajukan permohonan tenaga kerja dengan mengajukan kartu AK/III. Disnaker mengantarkan pencari kerja kepemberi kerja untuk mengikuti seleksi. Pelaksanaan penempatan tenaga kerja di Kota Malang telah sesuai dengan ketentuan Permenaker No.39 Tahun 2019. Kendala yang dihadapi adalah biaya transportasi
\end{abstract}


petugas antar kerja dan perusahaan tidak melaporkan kebutuhan tenaga kerja ke Dinas Tenaga Kerja.

Kata Kunci: PenempatanTenaga Kerja, PencariKerja, PetugasAntarKerja

\section{PENDAHULUAN}

Pekerjaan merupakan hal yang sangat penting dalam mewujudkan kehidupan yang sejahtera dalam suatu keluarga. Istilah pekerjaan dapat diartikan sebagai rangkaian tugas yang dirancang untuk dikerjakan seseorang dengan imbalan berupa upah atau gaji sesuai kualifikasi dan berat ringannya suatu pekerjaan ${ }^{1}$.

Pada saat ini jumlah lapangan pekerjaan belum sebanding dengan jumlah penduduk yang berada pada usia produktif (usia kerja) yang oleh BPS dibatasi antara 15 tahun sampai dengan 64 tahun. Jumlah tenaga kerja yang belum memiliki pekerjaan atau pengangguran berdasarkan pendidikannya dapat dilihat dalam tabel 1 .

Tabel 1. Jumlah pengangguran di Indonesia pada tahun 2015 dan 2016 berdasarkan pendidikan tertinggi yang ditamatkan ${ }^{2}$.

\begin{tabular}{llcrr}
\hline No. & $\begin{array}{l}\text { Pendidikan Tertinggi } \\
\text { yang Ditamatkan }\end{array}$ & $\begin{array}{c}\text { Februari } \\
\mathbf{2 0 1 5}\end{array}$ & \multicolumn{1}{c}{$\begin{array}{c}\text { Agustus } \\
\mathbf{2 0 1 5}\end{array}$} & \multicolumn{1}{c}{$\begin{array}{c}\text { Februari } \\
\mathbf{2 0 1 6}\end{array}$} \\
\hline 1. & Tidak/belum pernah & 124.303 & 55.554 & 94.293 \\
& sekolah & & & \\
2. & Tidak/belum tamat SD & 603.194 & 371.542 & 557.418 \\
3. & SD & 1.320 .652 & 1.004 .961 & 1.218 .954 \\
4. & SLTP & 1.650 .387 & 1.373 .919 & 1.313 .815 \\
5. & SLTA Umum/SMU & 1.762 .411 & 2.280 .029 & 1.546 .699 \\
6. & SLTA Kejuruan/SMK & 1.174 .366 & 1.569 .690 & 1.348 .327 \\
7. & Akademi/diploma & 254.312 & 251.541 & 249.362 \\
8. & Universitas & 565.402 & 653.586 & 695.304 \\
\hline & Jumlah & $\mathbf{7 . 4 5 4 . 7 6 7}$ & $\mathbf{7 . 5 6 0 . 8 2 2}$ & $\mathbf{7 . 0 2 4 . 3 6 2}$
\end{tabular}

\section{(Sumber:Badan Pusat Statistik, 2017)}

Berdasarkan tabel tersebut terlihat bahwa jumlah pengangguran dalam tiga kali pengukuran mengalami naik turun. Tahun 2016 mengalami penurunan sekitar 536.000 orang. Pengangguran terbanyak adalah pada lulusan SLTA yaitu 1.546.699 orang. Upaya untuk mengatasi pengangguran menurut Adrian Sutediada dua, yaitu: (a) mendorong pertumbuhan sektor padat karya serta memberikan kredit kepada pengusaha kecil dan pekerja mandiri, dan (b) angkatan kerja berpendidikan tinggi dipersiapkan untuk membuka lapangan usaha ${ }^{3}$.

Pengaturan tentang berbagai hal yang berkaitan dengan ketenaga kerjaan telah ditetapkan oleh negara sebagai upaya untuk memberikan perlindungan terhadap berbagai pihak yang terlibat. Bidang ketenagakerjaan yang dimaksud adalah menyangkut dua istilah, yaitu: (1) tenaga kerja, buruh, karyawan, dan pekerja yang menunjuk pada orang yang melakukan pekerjaan, dan (2) majikan, pemberi kerja dan pengusaha,

\footnotetext{
${ }^{1}$ Pusat Data dan Informasi Ketenagakerjaan Badan Penelitian, Pengembangan dan Informasi. 2013. Karakteristik Ketenagakerjaan Umum Kabupaten/Kota di Indonesia Tahun 2012. Kementerian Tenaga Kerja dan Transmigrasi RI. Jakarta.

2 Badan Pusat Statistik. 2017. Pengangguran Terbuka Menurut Pendidkan Tertinggi yang Ditamatkan 1986-2016. Online. https://www.bps.go.id/linkTabelStatis/view/id/972. Diakses tanggal 12 Januari 2017.

${ }^{3}$ Adrian Sutedi, Hukum Perburuhan, PT. Sinar Grafika. Jakarta, 2008, Hal. 7-8.
} 
untuk menunjuk pada orang yang memberikan pekerjaan ${ }^{4}$. Ketenagakerjaan dalam peraturan tersebut dinyatakan sebagai segala hal yang berkaitan dengan tenaga kerja pada waktu sebelum, selama, dan sesudah masa kerja. Sebelum kerja dimaksudkan sebagai kegiatan yang dilakukan sebelum bekerja di suatu perusahaan/tempat kerja, misalnya pelatihan kerja atau perekrutan/seleksi calon pekerja. Selama kerja bentuk kegiatannya dapat berupa jenis jabatan atau pekerjaan itu sendiri, pelatihan, promosi jabatan, dan lainnya.

Perekrutan pekerja berkaitan dengan persyaratan kerja dan proses seleksi yang dilakukan untuk menentukan calon pekerja yang akan dipilih untuk menjadi pekerja. Proses ini dilaksanakan untuk memilih calon pekerja atau menempatkan tenaga kerja sesuai keahlian, bakat, minat, dan kemampuannya.

Penempatan tenaga kerja yang langsung mendapatkan pembinaan langsung dari kementerian Dinas Tenaga Kerja secara khusus diatur dalam Peraturan Menteri Tenaga Kerja No.39 Tahun 2016 tentang Penempatan Tenaga Kerja. Peraturan tersebut merupakan pengganti dari Permenakertrans No.VII tahun 2008 tentang Penempatan Tenaga Kerja. Ketentuan tersebut mengatur tugas dan kedudukan perusahaan/pemberi keja, tenaga kerja, dan instansi terkait dalam penempatan kerja.

Kota Malang sebagai salah satu kota terbesar nomor dua di Jawa Timur memiliki jumlah penduduk yang cukup padat. Pertambahan penduduk selain dari kelahiran juga dari banyaknya warga luar kota Malang yang masuk ke Kota Malang untuk melanjutkan studi. Warga dari luar kota tersebut pada akhirnya seringkali tidak kembali ke daerah asalnya karena sudah mendapatkan pekerjaan di Kota Malang, khususnya pekerjaan di sektor pendidikan. Pada tahun 2015 jumlah angkatan kerja yang belum memiliki pekerjaan di Kota Malang berjumlah 29.606 orang $^{5}$. Pengangguran laki-laki berjumlah 19.443 orang dan 10.162 orang perempuan.

Pemerintah melalui Dinas Tenaga Kerja memiliki tanggung jawab untuk melaksanakan penempatan kerja sebagaimana diatur dalam Undang-Undang No.13 tahun 2003 tentang Ketenagakerjaan yang selanjutnya secara teknis diatur dalam Permenaker No.39 tahun 2006. Pelaksanaan penempatan tenaga kerja dilakukan dengan memperhatikan pemerataan kesempatan kerja dan penyediaan tenaga kerja sesuai kebutuhan program nasional dan daerah ${ }^{6}$. Perusahaan sebagai pihak yang menggunakan tenaga kerja berdasarkan peraturan perundang-undangan yang berlaku harus selalu melaporkan tentang adanya lowongan pekerjaan dan keadaan pekerja di perusahaannya secara berkala kepada dinas ketenagakerjaan. Disnaker bertugas untuk mendata dan melakukan pengawasan terhadap perusahaan berkaitan dengan tenaga kerjanya.

Tujuan penulisan artikel ini adalah untuk mendeskripsikan 3 (tiga) hal, yaitu: (1) mekanisme penempatan tenaga kerja menurut ketentuan Peraturan Menteri Tenaga Kerja No.39 tahun 2016 tentang Penempatan Tenaga Kerja, (2) prosedur penempatan kerja di Kota Malang, (3) kesesuaian antara pelaksanaan perekrutan tenaga kerja dalam Permenaker No.39 Tahun 2019 tentang Penempatan Tenaga Kerja dengan pelaksanaannya di Kota Malang.

\footnotetext{
${ }^{4}$ Abdul Rachmad Budiono, Hukum Perburuhan. PT. Indeks:Jakarta, 2011, Hal.11.

${ }^{5}$ Iqbal. 2016. Alamak, 29.606 Pengangguran ada di Kota Malang. Jawa Pos Radar Malang Online. http:// radarmalang.co.id/alamak-29-6060-pengangguran-ada-di-kota-malang-41627.htm. Diakses tanggal 24 Januari 2017.

${ }^{6}$ HardijanRusli.. 2011. Hukum Ketenagakerjaan, Berdasarkan UU No.13 No. 13/2003 tentang Ketenagakerjaan dan Peraturan Terkait Lainnya. Ghalia Indonesia. Bogor. Hal 21.
} 
Jenis penelitian ini adalah penelitian socio legal yang bertujuan untuk mengetahui kesesuaian antara peraturan tentang prosedur penempatan tenaga kerja dengan pelaksanannya di Kota Malang7. Pendekatan penelitian menggunakan pendekatan kasus dan peraturan perundang-undangan.

Sumber data dalam penelitian ini terdiri atas sumber data primer dan sumber data sekunder. Sumber data primer adalah Pegawai Dinas Tenaga Kerja bagian penempatan tenaga kerja Kota Malang. Sumber data sekunder adalah peraturan perundangundangan, yaitu: (1) Undang-Undang No.13 tahun 2003 tentang Ketenagakerjaan, (2) Permenaker No.39 tahun 2016 tentang Penempatan tenaga Kerja, (3) dokumen pengajuan laporan tentang pembukaan lowongan pekerjaan, foto prosedur pelaksanaan penempatan tenaga kerja.

Tehnik pengumpulan data menggunakan wawancara dan studi dokumen. Wawancara adalah tehnik pengumpulan data dengan cara tanyajawab secara sistematis dengan tatap muka. Hal ini untuk mengetahui secara mendalam berbagai hal yang berkaitan dengan prosedur penempatan tenaga kerja di Kota Malang. Hasil wawancara merupakan data yang utama dalam penelitian ini. Dalam memperoleh data yang pertama kali diwawancarai adalah Pegawai Dinas Tenaga Kerja bagian kesempatan tenaga kerja. Tujuannya untuk menggali informasi mengenai: (1) prosedur penempatan tenaga kerja, (2) pihak-pihak yang terlibat dalam penempatan tenaga kerja, (3) ketertiban perusahaan dalam membuat laporan atau informasi tentang lowongan pekerjaan, (4) tugas dinas tenaga kerja dalam penempatan tenaga kerja.

Dokumentasi merupakan salah satu bentuk dimana peneliti menggunakan dokumen yang relevan dengan masalah penelitian yang memanfaatkan dan menganalisis berbagai catatan atau dokumen lain yang dipercaya. Umumnya diartikan sebagai catatan atau keterangan tertulis dari peristiwa masa lalu. Sehubungan dengan itu metode dokumentasi ini dimaksudkan sebagai cara pengambilan data berdasarkan benda-benda tertulis, arsip serta foto-foto yang dapat memberikan informasi atau keterangan untuk keperluan penelitian. Dokumentasi dalam hal ini cukup penting terutama data tentang: (1) laporan perusahaan berkaitan dengan jumlah tenaga kerja yang dibutuhkan, (2) buku panduan penempatan kerja, dan dokumen lainnya.

Analisis data dilakukan selama penelitian masih di lapangan dan pada saat data telah terkumpul. Pada saat peneliti berada di lapangan analisis data yang digunakan untuk penelitian adalah analisis model interaktif, tujuannya untuk mendapatkan kelengkapan informasi yang mungkin kurang lengkap saat wawancara terdahulu. Setelah data yang diperlukan terkumpul, proses analisis data dilanjutkan dengan menggunakan lima jenis analisis data dalam penelitian kualitatif.

Dalam penelitian ini peneliti menggunakan dua jenis teknik analisis data yaitu analisis domain dan teknik analisis taksonomi ${ }^{8}$. Analisis domain digunakan untuk memperoleh gambaran atau pengertian yang bersifat umum dan relatif menyeluruh tentang fokus atau pokok permasalahan yang diteliti. Hasil analisis domain ini selanjutnya dijadikan titik tolak pada masalah-masalah yang lebih rinci dan mendalam yaitu dengan analisis taksonomi yang berguna bagi upaya mendeskripsikan atau menjelaskan fokus yang menjadi sasaran penelitian. Analisis taksonomi merupakan tindak lanjut setelah penyajian data secara umum, yaitu membahas lebih rinci dan mendalam dalam setiap permasalahan.

\footnotetext{
${ }^{7}$ Candra Kusuma. 2013. PenelitianInterdisiplinerTentangHukum. Epistema Institute. Jakarta. Hal.80.jenis

${ }^{8}$ Burhan Bungin, nalisis Data PenelitianKualitatif, PT. Raja GrafindoPersada, Jakarta, 2015, Hal. 85-94
} 


\section{PEMBAHASAN}

\section{Mekanisme Penempatan Tenaga Kerja Menurut Ketentuan Peraturan Menteri Tenaga Kerja No.39 tahun 2016 tentang Penempatan Tenaga Kerja}

Penempatan kerja yang merupakan suatu proses layanan untuk membantu pencari kerja mendapatkan pekerjaan mempunyai posisi strategis sebagai penyalur tenaga kerja secara tepat dan membantu perusahaan untuk mendapatkan pekerja berkualitas yang sesuai kebutuhan perusahaan ${ }^{9}$. Layanan prosedur penempatan tenaga kerja dalam Permenaker 39 tahun 2016 diatur dalam Pasal 37 sampai denganPasal 56 yang secara rinci mengatur: (1) bagian umum, (2) pencari kerja, (3) pemberi kerja, (4) lembaga penempatan tenaga kerja swasta, (5) bursa kerja khusus, (6) orientasi pra pemberangkatan, (7) pameran kesempatan kerja, dan (8) petugas pelayanan penempatan tenaga kerja.

Bagian umum yang terdiri atas 1 pasal yaitu Pasal 37 mengatur tentang media atau cara yang digunakan untuk layanan penempatan tenaga kerja yang dapat dilakukan secara manual dengan mendatangi langsung dinas tenaga kerja di kota/ kabupatenmasing-masing atau melalui sistem online yang terintegrasi dengan sistem pelayanan penempatan tenaga kerjanasional.

Bagian kedua dari mekanisme penempatan tenaga kerja mengatur tentang pencari kerja yang berkewajiban untuk mendaftarkan diri kedinas kabupaten/kota atau kecamatan sesuai domisili dari pencari kerja untuk mendapatkan tanda bukti pendaftaran pencari kerja atau sering disingkat dengan istilah AK/I. Pencari kerja dapat juga mendaftarkan kartu tersebut di luar kota/kabupaten domisili pencari kerja. Kartu AK/I berisi beberapa hal tentang identitas dari pencari kerja, yaitu : nama, tempat tanggal lahir, jenis kelamin, status, agama, alamat, pendidikan formal, dan keterampilan yang dimiliki. Pendaftaran dapat dilakukan secara manual, langsung mendatangi kantor dinas terkait dengan mengisi berkas-berkas yang telah disediakan atau system online yang langsung terhubung secara nasional. Beberapa lampiran yang harus disertakan dalam pendaftaran tersebut adalah ${ }^{10}$ : (a) foto copy KPT yang masih berlaku, (b) pas foto terbaru ukuran $3 \times 4 \mathrm{~cm}$ sebanyak 2 lembar, (c) foto copy ijazah terakhir, (d) foto copy sertifikat kompetensi kerja bagi yang memiliki, (e) foto copy keterangan pengalaman kerja bagi yang memiliki.

Pihakyang menandatangani kartu AK/Iadalah fungsional pengantarkerjaatau pejabat struktural dinas tenaga kerja bagi yang belum memiliki tenaga fungsional pengantar kerja. Kartu pencari kerja berlaku selama 2 (dua) tahun dan dapat diperpanjang ${ }^{11}$. Tiap 6 (enam) bulan sekali pencari kerja yang belum mendapatkan pekerjaan harus melapor ke dinas kota/kabupaten setempat dihitung sejak tanggal pendaftaran ${ }^{12}$. Pencari kerja yang telah mendapatkan pekerjaan harus melaporkan kedinas kabupaten/kota paling lambat 1 (satu) minggu setelah penerimaan. Pelaporan dapat dilakukan secara manual atauonline system yangberlakusecaranasional.

Pendaftaran pencari kerja di dinas tenaga kerja atau kecamatan dilaksanakan oleh fungsional pengantar kerja atau petugas antar kerja. Petugas tersebut bertugas untuk mengisi data pencari kerja atau AK/II dengan melakukan wawancara langsung kepada pencari kerja untuk mengetahui bakat, minat, dan kemampuan dari pencari kerja.

\footnotetext{
${ }^{9}$ Pasal 1 ayat (1) Peraturan Menteri Ketenagakerjaan No.39 Tahun 2016 tentangPenempatan Tenaga Kerja.

${ }^{10}$ Pasal 38 ayat (2) Peraturan Menteri Ketenagakerjaan No.39 Tahun 2016 tentangPenempatan Tenaga Kerja.

${ }^{11}$ Pasal 39 ayat (3) Peraturan Menteri Ketenagakerjaan No.39 Tahun 2016 tentangPenempatan Tenaga Kerja.

${ }^{12}$ Pasal 39 ayat (4) Peraturan Menteri Ketenagakerjaan No.39 Tahun 2016 tentangPenempatan Tenaga Kerja.
} 
Dalam format AK/II berisi tentang identitas pencari kerja, mulai dari nama, tanggal lahir sampai dengan pendidikan. Selain itu juga terdapat isian ${ }^{13}$ : (a) bahasa yang dikuasai, (b) pengalaman kerja, yang terdiri atas jabatan, uraian tugas, lama kerja, dan pemberi kerja, (c) catatan dari pengantar kerja, (d) jabatan yang diinginkan, (e) lokasi penempatan, dan (f) lokasi penempatan, (g) upah yang diinginkan.

Bagian ketiga mengatur tentang pemberi kerja yang meliputi pelaksanaan perekrutan tenaga kerja, kewajiban pemberi kerjauntu kmenyampaikan laporan tentang adanya lowongan pekerjaan ke dinas tenaga kerja. Pemberi kerja atau perusahaan yang membutuhkantenagakerjadapatmelakukanperekrutansendiri, melaluidinaskabupaten/ kota, Lembaga Penempatan Tenaga KerjaSwasta (LPTKS), dan Balai PelatihanKerja melalui Antar Kerja.Pemberikerjayang membutuhkan tenaga kerja harus menyampaikan informasi adanya lowongan pekerjaan secara manual atau online kepada dinas kota/ kabupaten setempat. Dinas tenaga kerja kota/kabupaten yang menerima laporan adanya lowongan pekerjaan harus mencatat dalam daftar isian permintaan tenaga kerja atau AK/III dan mengeluarkan bukti lapor lowongan pekerjaan secara manual atauonline system.

Kartu permintaan tenaga kerja berisi tentang:(a) identitas perusahaan yang meliputi nama pemberi kerja, lapangan usaha, alamat, kontak person, dan jabatan, (b) informasi lowongan jabatan/pekerjaan, nama jabatan yang ditawarkan dan jumlahtenaga yang dibutuhkan dengan, diklasifikasikan jumlahlaki-laki dan perempuan, (c) pendidikan formal, keterampilan, pengalaman, dan syaratkhusus, (d) system pengupahan, (borongan, harian, mingguan, ataubulanan), gaji/upah (sebulan), jumlah jam kerja (seminggu), dan jaminan social, (e) uraiansingkatpekerjaan, dan (f) uraiantugas ${ }^{14}$.

Dinas tenaga kerja melakukan pemeriksaan terhadap adanya kesesuaian persyaratanjabatan dalam lowongan pekerjaan dengan kualifikasi yang dimiliki oleh pencari kerja. Untuk memenuhi lowongan yang dibutuhkan perusahaan, Dinas Tenaga Kerja melakukan pemanggilan terhadap pencari kerja yang memenuhi kualifikasi dengan menggunakan kartu Antar kerja atau AK/IV baik secara manual atau online.

Kartu pemanggilan tersebut berisi tentang pemanggilan pencari kerja untuk hadir ke Dinas Tenaga Kerja terkait untuk membicarakan adanya lowongan pekerjaan. Dinas akan menyampaikan lowongan yang terdapat dalam AK/III dan memfasilitasi pencari kerja untuk melakukan lamaran kepemberi kerja dengan menerbitkan Kartu Antar kerja atau AK/V yang berisi tentang identitas pelamar, kartu pendaftaran/kode jabatan, dan isian jenis lowongan pekerjaan yang sesuai. Berdasarkan ketentuan-ketentuan dalam mekanisme penempatan tenaga kerja di atas maka dapat digambarkan skema mekanisme penempatan tenaga kerja sebagaimana digambarkan dalam gambar 1 .

\section{Gambar 1. Skema layanan instansi pemerintah yang bertanggung jawab dalam bidang ketenagakerjaan dalam layanan penempatan tenaga kerja berkaitan dengan pencari kerja dan pemberi kerja.}

\footnotetext{
${ }^{13}$ Lampiran Peraturan Menteri Ketenagakerjaan No.39 Tahun 2016 tentangPenempatan Tenaga Kerja. Format 3 huruf b.

${ }^{14}$ Lampiran Peraturan Menteri Ketenagakerjaan No.39 Tahun 2016 tentangPenempatan Tenaga Kerja.Format 3 huruf $c$.
} 


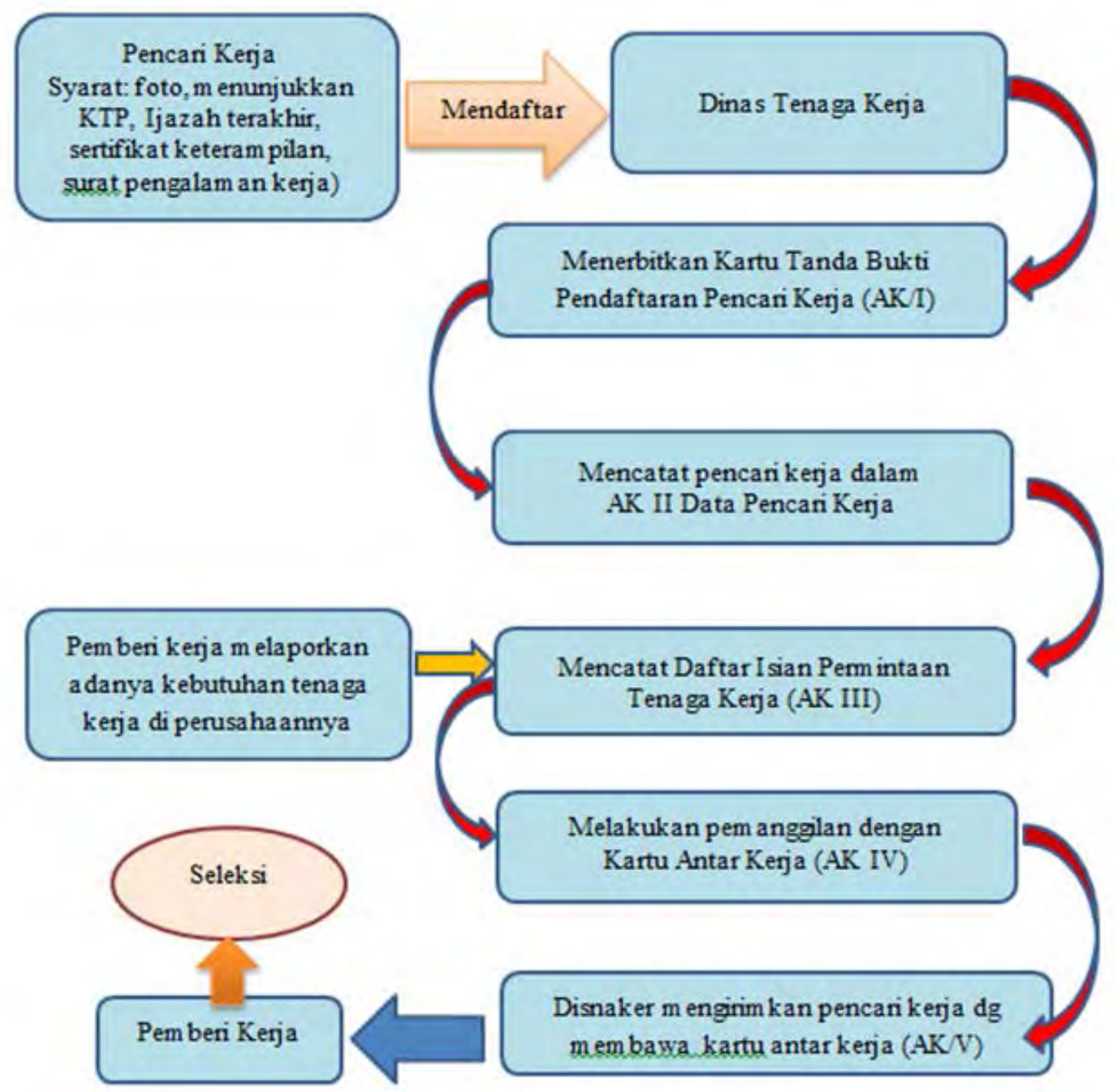

(Sumber: Permenaker No.39 tahun 2016 tentang Penempatan Tenaga Kerja)

Mekanisme dalam penempatan tenaga kerja yang berhubungan dengan pencari kerja, pemberi kerja, dan instansi yang berwenang dalam layanan penempatan tenaga kerja sebagai berikut.

1. Pencari kerja mendaftarkan diri ke Dinas Tenaga Kerja Kabupaten/Kota atau kecamatan secara manual atau online untuk mendapatkan AK/I.

2. Fungsional Pengantar Kerjaatau Petugas Antar Kerja mewawancarai dan mencatat bakat, minat, keterampilan, dan pengalaman pencari kerja dalam AK/II.

3. Pemberi kerja/perusahaan menyampaikan laporan ke Disnaker tentang adanya kebutuhan tenaga kerja di perusahaannya yang dicatat oleh Disnaker dalam AK/ III.

4. Disnaker mengecek kesesuaian antara kebutuhan tenaga kerja yang terdapat dalam AK/III dengan kualifikasi pencari kerja yang terdapat dalam AK/II dan dilanjutkan dengan menerbitkan AK/IV untuk memanggil pencari kerja.

5. Disnaker menerbitkan Kartu Antar Kerja untuk dibawa pencari kerja ke perusahaan yang membutuhkan tenaga kerja dan dilanjutkan dengan seleksi.

Pemberi kerja yang berencana mengerahkan tenaga kerja dari beberapa provinsi harus mempunyai Surat Persetujuan Penempatan Antar Kerja Antar Daerah (SPP AKAD) yang dikeluarkan oleh Direktur Jenderal secara manual atau online. Permohonan SPP 
AKAD disampaikan dengan melampirkan ${ }^{15}$ : (a) daftar isian kegiatan rencana kebutuhan tenaga kerja (DIK-RKTKAD), (b) rencana perjanjian kerja yang telah disahkan oleh Dinas Kabupaten/Kota tujuan penempatan tenaga kerja AKAD, (c) surat rekomendasi persetujuan menerima dan mendatangkan tenaga kerja AKD dari Kepala Provinsi tujuan Penempatan Tenaga Kerja AKAD. Perusahaan kontraktor atau pemborong harus menyertakan bukti kontrak kerja borongan atau surat perintah kerja pemborongan.

Lembaga Penempatan Tenaga Kerja Swasta (LPTKS) yang melakukan pelayanan penempatan tenaga kerja melalui system AKL dalam satu daerah Kabupaten/Kota berkewajiban untuk: (a) melaporkan job order dari pemberi kerja kepada Dinas Kabupaten/Kota, (b) melibatkan Dinas Kabupaten/Kota dalam proses rekrutmen tenaga kerja, (c) mengesahkan perjanjian kerja pada Dinas Kabupaten/Kota, (d) melaporkan penempatan tenaga kerjasecara online atau manual kepada Binas Kabupaten/Kota.

LPTKS yang melakuka nlayanan penempatan tenaga kerja system Antar Kerja Lokal (AKL) wajib memiliki SPP AKL yang diterbitkan oleh dinas provinsi. LPTKS harus mengajukan permohonan secara manual atau online untuk memperoleh SPP AKL denganmenyertakan: (a) daftar isian kegiatan rencana kebutuhan tenaga kerja (DIKRKTKL), (b) rancangan perjanjian kerja yang telah disahkan oleh Dinas Kabupaten/ kota, (c) surat persetujuan menerima tenaga kerja dari dinas Kabupaten/Kota tujuan penempatan tenaga kerja, (d) foto copy Surat Ijin Usaha LPTKS, dan (e) bukti adanya permintaan/job order dari pemberi kerja. LPTKS yang melakukan penempatan tenaga kerja melalui system AKAD wajib memiliki SPP AKAD yang diterbitkan oleh DirekturJenderalcq. DirekturPenempatan Tenaga KerjaDalam Negeri dan Pemberi Kerja. Pengajuan surat permohonan disertai dengan surat rekomendasi rekruitmen dan seleksi calon tenaga kerja AKAD dari Dinas Provinsi.

Pemberi kerja yang membutuhkan tenaga kerja melalui Bursa Kerja Khusus (BKK) wajib mengajukan permohonan ke Dinas Kabupaten/Kota tempat domisili BKK untukmendapatkan persetujuan. Permohonan disertai dengan rancangan perjanjian kerja yang sudah disahkan oleh Dinas Kabupaten/Kota tujuan Penempatan Tenaga Kerja.

Pelaksana penempatan tenaga kerja wajib mengadakan orientasi pra pemberangkatan yang berisi penjelasan tentang ${ }^{16}$ : (a) perjanjiankerja, (b) kondisiling kungan kerja, budaya kerja, dan kebiasaan penduduk/masyarakat di daerah tujuan penempatan, dan (c) mental, disiplin, dan etoskerja. Orientasi yang dilakukan oleh LPTKS atau BKK harus dilaksanakan Bersama dengan dinas kabupaten/kota.

Pemberi kerja dapat mengadakan pameran kesempatan kerja untuk menjaring tenaga kerja melalui suatu pameran atau job fair. Pameran dapat diselenggarakan oleh kementerian/instansi pemerintah, dinas provinsi, dinas kabupaten/kota, LPTKS, BKK, atau lembaga berbadan hukum. Pameran yang diselenggarakan oleh LPTKS, dan BKK, dan lembaga berbadan hukum harus memperoleh persetujuan dari Dinas Kabupaten/ Kota. Penyelenggara tersebut harus mengajukan permohonan dengan menyertakan ${ }^{17}$ : (a) SIU LPTKS, tanda daftar BKK, atau akta pendirian berbadan hukum, (b) rencanajumlah perusahaan peserta, (c) perkiraan lowongan dan penempatan yang ditargetkan, dan (d) surat pernyataan dari penanggungjawab kegiatan untuk tidak memungutbiaya dari

${ }_{15}$ Pasal 50 huruf a, b,c, d, dan e Peraturan Menteri Ketenagakerjaan No.39 Tahun 2016 tentangPenempatan Tenaga Kerja.

${ }^{16}$ Pasal 52 ayat (3)Peraturan Menteri Ketenagakerjaan No.39 Tahun 2016 tentangPenempatan Tenaga Kerja

${ }^{17}$ Pasal 54 ayat (2) Peraturan Menteri Ketenagakerjaan No.39 Tahun 2016 tentangPenempatan Tenaga Kerja. 
pengunjung. Kegiatan pameran akan dihentikan jika melakukan pemungutan kepada pengunjung.

Petugas pelayanan penempatan tenaga kerja adalah fungsional pengantar kerja yang berada pada pemerintahan bidang ketenaga kerjaan, baikdi pusat, dinas provinsi, dan dinas Kabupaten/Kota yang dilakukan oleh. Dinas Provinsi atau kota yang belum memiliki pengantar kerja harus membentuk petugas antar kerja yang ditunjuk oleh pejabat yang berwenang dalam penempatan tenaga kerja dan perluasan kesempatan kerja. Pelayanan penempatan tenaga kerja di LPTKS dan BKK dilakukan oleh petugas Antar kerja. Pengantar kerja dan petugas Antar kerja harus memiliki sertifikat yang diterbitkan oleh Lembaga SertifikasiProfesi.

\section{ProsedurPenempatan Tenaga Kerja di Kota Malang}

Penempatan tenaga kerja merupakan proses yang dilakukan oleh Dinas Ketenagakerjaan dalam menempatkan pencari kerja untuk memperoleh pekerjaan yang didasarkan atas kesesuaian antara keinginan pencari kerja dengan kualifikasi yang ditetapkan oleh pemberikerja. Dalam melaksanakan penempatan kerja, ada beberapa prosedur yang dilakukan oleh Dinas Ketenaga kerjaan Kota Malang. Berikut iniuraian tentang prosedur dan pihak-pihak yang terlibat dalam penempatan tenaga kerja di Kota Malang oleh Dinas Ketenagakerjaan dan Transmigrasi Kota Malang.

Prosedur penempatan tenaga kerja di Kota Malang diawali dengan pelaporan yang dilakukan oleh pencarikerja. Pencarikerja yang merupakanpenduduk Kota Malang maupunluar Kota Malang yang berusia 15 tahunataulebih yang mengangguratau yang sudah bekerja tetapi ingin pindah pekerjaan atau yang sedang mencari pekerjaan, diwajibkan untuk melaporke Disnakertrans agar memperoleh kartu AK/I yang biasa disebut dengan Kartu Kuning.

Kartu AK/I adalah kartu yang menandakan bahwa pencari kerja telah mendaftarkan dirinya untuk mencari pekerjaan. Hal-hal yang tercantum pada kartu AK/I meliputihalhal yang bersifat umum yaitu nomor pendaftaran pencari kerja, nama, tempat tanggal lahir, agama, status pernikahan, alamat, nomor telepon atau handphone yang dapat dihubungi, riwayat pendidikan formal dan keterampilan atau pengalaman kerja yang dimiliki disertai dengan pas foto ukuran $3 \times 4^{18}$. Kartu AK/I ini dilegalkan oleh Pengantar Kerja yang merupakan pejabat fungsional dalam Disnakertrans Kota Malang.

Kartu AK/I berlaku dalam kurun waktu 2 tahun dan harus diperbarui setiap enam (6) bulan sekali apabila pencari kerja belum mendapatkan pekerjaan. Idealnya pelaporan yang dilakukan setiap enam (6) bulan sekali oleh pencari kerja yang belum diterima kerja bertujuan agar penempatan kerja berjalan dengan maksimal. Pelaporan ini masih sebatas pendataan saja, seharusnya setelah pendataan pihak dinas Tenaga Kerja menindaklanjuti untuk menghubungkan dengan pemberi kerja. Dinas tidak menindaklanjuti ke pemberi kerja karena tidak adanya dana untuk biaya transportasi dan lainnya dalam pengurusan tersebut ${ }^{19}$.

Perbaikan kartu AK/I tiap enam (6) bulan sekali agar penempatan kerja dapat dilaksanakan secara optimal. Karena dengan adanya pelaporan yang dilakukan oleh pencari kerja, Disnaker dapat mengetahui permasalahan yang terjadi terkait tidak diterimanya pencari kerja. Setelah mengetahui permasalahan ini, memudahkan Disnakertrans untuk mengambil langkah dalam mengatasi permasalahan tersebut.

\footnotetext{
${ }^{18}$ Dokumentasiberdasarkankartu AK/I yang terdapat di Dinas Tenaga Kerja Kota Malang. 2017.

${ }^{19}$ Hasil wawancaradengan Bapak Manake Bambang Triawan, S.E, PegawaiDinas Tenaga Kerja Kota Malang bagianPengantarKerja, pada tanggal 3 Agustus 2017.
} 
Kenyataannya walaupun pihak Disnaker mengetahui permasalahan pencari kerja untuk mendapatkan pekerjaan akan tetap sulit untuk menindaklanjutinya karena adanya kendala pada minimnya anggaran yang diberikan Pemerintah Kota Malang (sebagai akibat dari adanya otonomi daerah), upaya untuk pengoptimalan penempatan tenaga kerja belum dapat dilaksanakan dengan baik.

Untuk memperoleh Kartu AK/I, pencari kerja harus datang ke Disnaker. Sebelum mendapatkan Kartu AK/I, pencari kerja menjalani sesi wawancara dengan Pengantar Kerja untuk mengetahui keterangan umum dan keterangan khusus yang dimiliki pencari kerja. Keterangan umum yang dimaksud adalah latar belakang pencari kerja yang meliputi nomorpendaftaranpencarikerja, nama, tempattanggallahir, agama, status pernikahan, alamat, nomor telepon atau handphone yang dapat dihubungi, riwayat pendidikan formal dan keterampilan atau pengalaman kerja yang dimiliki. Sedangkan keterangan khusus yang dimaksud adalah hal-hal yang meliputi keinginan pencari kerja untuk bekerja di perusahaan tertentu, jabatan yang diinginkan, dan upah yang diinginkan pencari kerja sesuai dengan opsi yang telah disediakan. Pedoman wawancara tersebut tertuang dalam Kartu Data Pencari Kerja (Kartu AK/II).

Kartu AK II memiliki fungsi sebagai catatan tentang pencari kerja untuk dijadikan dasar dalam Pengantar Kerja merekomendasikan pencari kerja untuk mendapatkan pekerjaan. Selain itu, Kartu AK/II ini juga memuat tentang data pencari kerja yang bersangkutan sudah ditempatkan atau belum sehingga kartu ini juga berfungsi sebagai bentuk laporan terkait penempatan kerja para pencari kerja. Setelah menjalani sesi wawancara, pencari kerja berhak untuk mendapatkan Kartu AK/I dan kualifikasi yang dimiliki pencari kerja berhak untuk dipasarkan.

Jadi, setelah pencari kerja mendaftarkan dirinya ke Disnaker dan diwawancarai dengan menggunakan format AK/II, pencari kerja dapat memperoleh Kartu AK/I. Dengan diperolehnya Kartu AK/I, Disnaker Kota Malang, khususnya Pengantar Kerja selaku pemegang jabatan fungsional di bidang penempatan tenaga kerja dapat memberikan pelayanan lebih lanjut yaitu dengan memasarkan pencari kerja yang telah mendaftar kepada pemberi kerja secara langsung dengan mendatangi perusahaan. Pemasaran pencari kerja selain dilakukan secara langsung, juga dapat dilakukan secara tidak langsung dengan menggunakan aplikasi yang ada di website kemnaker.go.id.

Pelayanan antar kerja yang sesungguhnya atau pemasaran pencarikerja secaralangsung dilakukan oleh pengantar kerja dengan melakukan pemanggilan pencari kerja. Pencari kerja dipanggil ke Disnaker Kota Malang, k emudian diantarkan keperusahaan yang membutuhkan pencari kerja sesuai dengan kualifikasi yang dimiliki pencari kerja. Pemanggilan yang dilakukan oleh Pengantar Kerja dilakukan dengan menggunakan Kartu Pemanggilan Pencari Kerja yang di dalamnya berisi tentang undangan agar pencari kerja datang ke kantor Disnaker untuk membicarakan tentang pekerjaan yang diminta/diingini oleh pencari kerja ${ }^{20}$.

Pencari kerja mendapatkan pelayanan dari Disnakertrans untuk ditempatkan secara langsung oleh Disnakertrans. Pencari kerja yang sudah mendaftar (yang sudah mempunyai Kartu AK/I) dapat dipanggil oleh Disnakertrans untuk ditempatkan di Perusahaan yang sedang membutuhkan pekerja. Dengan berpedoman pada data di Kartu AK/II, Disnakertrans dapat mencocokkan kualifikasi pencari kerja dengan kualifikasi yang diinginkan pemberi kerja yang sudah melapor ke Disnaker sehingga ketika ada pencari kerja yang cocok dengan kualifikasi perusahaan tertentu maka Disnker dapat melakukan panggilan kepada pencari kerja sesuai. Setelah melakukan pemanggilan

\footnotetext{
${ }^{20}$ Pasal 43 PeraturanPeraturan Menteri Ketenagakerjaan No.39 Tahun 2016 tentangPenempatan Tenaga Kerja
} 
sesuai dengan Kartu AK/IV, pencari kerja diantarkan kepemberi kerja dengan membawa Surat Pengantar (biasa disebut dengan Kartu AK/V) dari Disnaker Kota Malang. DalamKartu AK/V tersebut memuat rekomendasi dari Disnaker dan tenggang waktu untuk pemberi kerja dalam menjawab lamaran kerja yang diajukan. Ketika pemberi kerja menolak pencari kerja tersebut, pemberi kerja wajib menyertakan alasan tidak diterimanya pencari kerja tersebut. Alasan-alasan yang diberikan oleh pemberi kerja untuk menolak pencari kerja ini merupakan data untuk bidang pelatihan mengadakan pelatihan bagi para pencari kerja yang membutuhkan upgrade keterampilan para pencari kerja.

Disnaker Kota Malang khususnya Bidang Pelatihan dapat melakukan pelatihan peningkatan keterampilan pencari kerja sebagai bentuk pelayanan kepada pencari kerja. Pelatihan dapat dilakukan berdasarkan data yang diperoleh dari pemberi kerja yang tidak menerima pencari kerja yang diusulkan oleh Disnaker. Pencari kerja yang tidak diterima dapat mengikuti pelatihan yang dilaksanakan oleh Bidang Pelatihan Disnaker Kota Malang. Pelatihan juga diberikan kepada pencari kerja yang selama kurun waktu 6 (enam) bulan belum mendapatkan pekerjaan.

Pencari kerja yang belum mendapatkan pekerjaan selama kurun waktu enam (6) bulan berhak untuk mendapatkan pelatihan dari Disnakertrans Kota Malang khususnya Bidang Pelatihan. Namun, karena di Kota Malang belum ada Balai Latihan Kerja di bawah naungan Disnakertrans Kota Malang maka belum ada pejabat fungsional (Instruktur) yang ahli dalam memberikan pelatihan sehingga pelatihan yang diberikan juga kurang maksimal. Pelatihan kerja merupakan hal yang penting dalam meningkatkan keterampilan kerja pencari kerja sebagaimana hasil penelitian di Spanyol dalam tahun 2010-2012 yang menunjukkan pengaruh positif adanya pelatihan kerja terhadappeluang untuk mendapat kanpekerjaan ${ }^{21}$.

Pemasaran pencari kerja juga dapat dilakukan secara tidak langsung dengan menggunakan aplikasi yang ada di website kemnaker.go.id. Kualifikasi dari pencari kerja dapat dipasar kanmelalui aplikasi yang telah dibuat oleh Kementerian Ketenagakerjaan. Melalui aplikasi ini, pemberi kerja dapat melihat langsung data diri dari pencari kerja. Selain itu, pencari kerja juga dapat melihat langsung data dari pemberi kerja yang sedang membuka lowongan pekerjaan.

Berdasarkan pemaparan di atas dapat diringkas bahwa setelah memperoleh Kartu AK/I, pencari kerja dapat mencari pekerjaan sesuai dengan keinginannya. Pencari kerja dapat mengakses informasi pasar kerja melalui laman Disnaker Kota Malang, laman Kementerian Ketenagakerjaan RI secara online. Selain itu, pencarikerja juga dapatmemperoleh informasi pasar kerja melalui informasi pasar kerja yang ada di papan pengumuman Disnaker Kota Malang atau melalui berbagai media yang memuat informasi pasar kerjase perti koran, majalah, televisi dan lain sebagainya. Selainitu, pencari kerja juga berhak untuk ditempatkan sesuai dengan prosedur antar kerja yang sesungguhnya. Setelah berhasil ditempatkan, maka pencari kerjawaji buntuk melaporkan dirikeDisnaker Kota Malang bahwa pencari kerja yang bersangkutan telah diterima kerja. Dan apabila belum diterima kerja, maka pencari kerja wajib lapor dalam kurun waktu maksimal enam (6) bulan sejak pendaftaran agar dapat ditindaklanjuti sesuai denganprosedur sehingga dapat segera mendapat kanpekerjaan.

Dalam penempatan tenaga kerja di Kota Malang, setidaknya ada enam pihak yang sangat berperan, yaitu (1) Disnakertrans Bidang Penempatan, (2) Disnakertrans Bidang

\footnotetext{
${ }^{21}$ MaiteBlazquez, AinhoaHerrarte, dan Felipe Saez, Training and Job Search Assistance Programmes in Spain: The Case of Long-Term Unemployment, Journal of Policy Modelling, Volume 41 March 2019.
} 
Pelatihan, (3) Disnakertrans Bidang Hubungan Industrial, (4) Bursa Kerja Khusus (BKK), (5) Lembaga Penempatan Tenaga KerjaSwasta (LPTKS), dan (6) Pemberi Kerja. Disnakertrans Kota Malang dalam Bidang Penempatan memiliki 2 (dua) pejabat fungsional yang sangat berperan aktif dalam penempatan tenaga kerja yaitu Jabatan Pengantar Kerja. Kedua pegawai tersebut menjalankan tiga fungsi dalam penempatan tenaga kerja yaitu informasi pasar kerja, penyuluhan bimbingan dan jabatan, serta perantaraan kerja.

Pemberian informasi pasar kerja menggunakan dua cara, yaitu secara online maupun offline. Informasi pasar kerjasecara online dapat diaksesmelalui website resmiDisnakertrans Kota Malang atau website resmi Kementerian Ketenagakerjaan. Melaluia plikasi pada website resmi Kementerian Ketenagakerjaan pencari kerja diberikan kemudahan untuk melihat lowonganpe kerjaan yang ada di Kota Malang dan kota-kota lain di seluruh Indonesia bahkan sampai dengan luar negeri.

Pencari kerja dapat memasukkan curriculum vitae yang dimiliki melalui aplikasi ini sehingga pemberi kerja yang membutuhkan tenaga kerja dapat melihat data diri pencari kerja secara langsung. Begitu pula sebaliknya, pemberi kerja juga dapat mengumumkan lowongan kerja melalui aplikasi ini sehingga pencari kerja juga dapat melihat dan memilih lowongan kerja yang menarik dan memberikan peluang pekerjaan bagi pencari kerja tersebut.

Untuk mengakses informasi pasar kerja secarao ffline dapat dilakukan dengan melihat papan pengumuman lowongan pekerjaan yang disediakan di Kantor Disnakertrans Kota Malang. Papan pengumuman lowongan pekerjaan ini memuat informasi tentangperusahaan-perusahaan yang sedang membutuhkan tenaga kerjadi sertai dengan kualifikasi yang harus dipenuhi oleh pelamar/pencari kerja. Jadi, setelah pencari kerja mengurus Kartu AK/I, pencari kerja dapat memperoleh informasi kerja secara langsungmelalui papan pengumuman tersebut.

Selain menggunakan kedua cara tersebut, informasi pasar kerja juga dapat diperoleh ketika Disnakertrans Kota Malang yang diprakarsai oleh Jabatan Fungsional Pengantar Kerja melaksanakan kegiatan Job Market Fair. Disnakertrans Kota Malang mengagendakan kegiatan Job Market Fair selama empat kali dalam satu tahun. Biasanya Job Market Fair diadakan dengan melakukan kerjasama dengan perguruan tinggi atau sekolah menengah di Kota Malang. Pada kegiatan Job Market Fair, banyak perusahaanperusahaan yang mengajukan untuk mengikuti kegiatan tersebut demi mendapatkan tenaga kerja yang dibutuhkan. Namun, tidak semua perusahaan dapat mengikuti kegiatan tersebut melainkan harus melalui proses seleksi yang dilakukan oleh Pengantar Kerja Kota Malang. Sebagaimana Job Market Fair yang baru diadakan Disnakertrans Kota Malang pada tanggal 2-4 Agustus 2017 di Universitas Merdeka Kota Malang, hanya ada 80 perusahaan yang dapat mengikuti kegiatan tersebut.

Job Market Fair tidak hanya dilaksanakan sebagai bentuk informasi pasar kerja melainkan juga merupakan bentuk perantaraan kerja yang dilakukan oleh Pengantar Kerja.Jadi, ketika acara iniberlangsung, disana sudah disediakan bilik-bilik khusus untuk wawancara dan pengurusan kartu AK/I, sehingga pencari kerja yang belum mendaftar ke Disnakertrans dapat mendaftar di tempat Job Market Fair dilaksanakan. Setelah itu, pencari kerja yang telah mendaftar dapat memberikan CV yang dimiliki pencari kerja ke perusahaan-perusahaan yang ada di Job Market Fair tersebut. Sehinggaketika acara Job Market Fair iniselesai, Pengantar Kerja dapat melakukan pendataan terkait jumlah pencari kerja yang dapat diterima melalui Job Market Fair ini dan jumlah pencari kerja yang tidak diterima. Data yang diperoleh ini kemudian digunakan untuk salah satu 
bahan untuk pelaporan penempatan kerja yang telah dilakukan ketingkatprovinsi sampai kepusat yang dilakukan setiap awal bulan. Selain itu, data ini juga digunakan untuk mengambil langkah kedepannya untuk optimalisasi penempatan tenaga kerja.

Pengantar Kerja juga melakukan perantaraan kerja yang dimulai dengan pelayanan kepada pencari kerja dalam memperoleh Kartu AK/I sampai dengan proses antar kerja para pencari kerja baik antar kerja lokal, antar kerja daerah, maupun antar kerja nasional sehingga pencari kerja tersebut berhasil ditempatkan. Pengantar kerja juga memberikan pelayanan kepada pemberi kerja untuk memasarkan lowongan pekerjaan yang ada dalam perusahaan tersebut. Pengantar kerja tidak hanya sebatas memasarkan dan memberikan rekomendasi tetapi juga memberikan penyuluhan tentang analisis jabatan pada suatu perusahaan. Namun, karena ada kendala dalam hal anggaran, pelaksanaan penyuluhan terkait analisis jabatan belum dapat dilaksanakan dengan baik.

Pihak yang juga sangat berperan dalam penempatan tenaga kerja adalahDisnakertrans Bidang Pelatihan. Peran Disnakertrans Bidang Pelatihan Kota Malang adalah melatih tenaga kerja yang belum diterima dalam penempatan kerja. Peserta pelatihan adalah pencari kerja yang dalam kurun waktu enam (6) bulan belum mendapatkan pekerjaan dan pencari kerja yang direkomendasikan Disnakertrans Kota Malang tetapi tidak diterima. Pelatihan dilakukan untuk meningkatkan keterampilan pencari kerja terutama soft skill karena banyak dijumpai pencari kerja yang kemampuan soft skillnya sangat kurang. Sehingga dengan diadakannya pelatihan, pencari kerja yang keterampilannya meningkatakan lebih mudah mendapatkan pekerjaan.

Disnakertrans Bidang Hubungan Industrial memiliki peran yang cukup penting dalam penempatan tenaga kerja, yaitu memberikan bantuan pemahaman kepada pencari kerja terkait dengan perjanjian kerja yang dilakukan pencari kerja dengan pemberikerja. Disnakertrans Bidang Industrial Kota Malang memberikan bekal kepada pencari kerja tentang tata cara perjanjian kerja. Pejabat Fungsional dalam Bidang Industrial juga menjadi mediator antarap encari kerja dan pemberi kerja yang berkaitan denganberbagai permasalahan industrial, misalnya upah yang tidak sesuai dengan UMK, jaminan sosial, konflik antara serikat kerja dengan perusahaan dan berbagai masalah lainnya.

\section{Kesesuaian Pelaksanaan Mekanisme Penempatan Tenaga Kerja di Kota Malang dengan Peraturan Menteri Tenaga Kerja No. 39 tahun 2016 tentangPenempatan Tenaga Kerja.}

Mekanisme penempatan tenaga kerja dalam Permenaker No.39 tahun 2016 mengatur tentang pemberian layanan kepada pencari kerja untuk mendapatkan pekerjaan, pemberi kerja untuk mendapatkan tenaga kerja, dan kewajiban Dinas Tenaga Kerja untuk memfasilitasinya. Layanan bagi pencari kerja meliputi layanan untuk mendapatkan kartu pencari kerja yang datanya disimpan di Disnaker. Data tersebut dapat digunakan oleh Disnaker untuk mencarikan lowongan pekerjaan yang disesuaikan dengan data lowongan pekerjaan dari perusahaan.

Mekanisme penempatan tenaga kerja yang terdapat dalam Permenaker No.39 tahun 2016 dalam pelaksanaannya akan dibandingkan dengan pelaksanaan di lapangan yaitu di Kota Malang. Permenaker tersebut mengatur beberapa hal, diantaranya berkaitandengan: (a) mekanisme penempatan tenaga kerja, (b) pihak yang terlibat dalam penempatan tenaga kerja, peranan fungsional Pengantar Kerja/Petugas Antar kerja, LPTKS yang melakukan perekrutan tenaga kerja, BKK yang melakukan perekrutan tenaga kerja, (c) laporan adanya lowongan pekerjaan bagi perusahaan yang membutuhkan tenagakerja, 
(d) pameran bursa kerja (job fair) yang mengajukan ijin keDisnaker dan gratis, (e) penyelenggaraan pra orientasi sebelum masuk dalam pekerjaan.

Pencari kerja untuk memperoleh pekerjaan harus secara pro aktif mendaftarkan diri untuk mendapatkan kartu pencari kerja, dan yang terpenting adalah didata oleh Disnaker. Tujuannya jika sewaktu-waktu ada lowongan pekerjaan yang sesuai dengan kualifikasi dari pencari kerja pihak Disnaker dapat menyalurkan tenaga kerja tersebut. Disnaker secara aktif melakukan wawancara, pencatatan, pemanggilan, membuatkan surat pengantar kepada pencari kerja. Secara rinci alur mekanisme penempatan tenagakerja menurut Permenaker digambarkan dalam gambar 2.

Gambar 2.Alur layanan yang diberikan Dinas Tenaga Kerja kepada pencari kerja dan pemberi kerja.

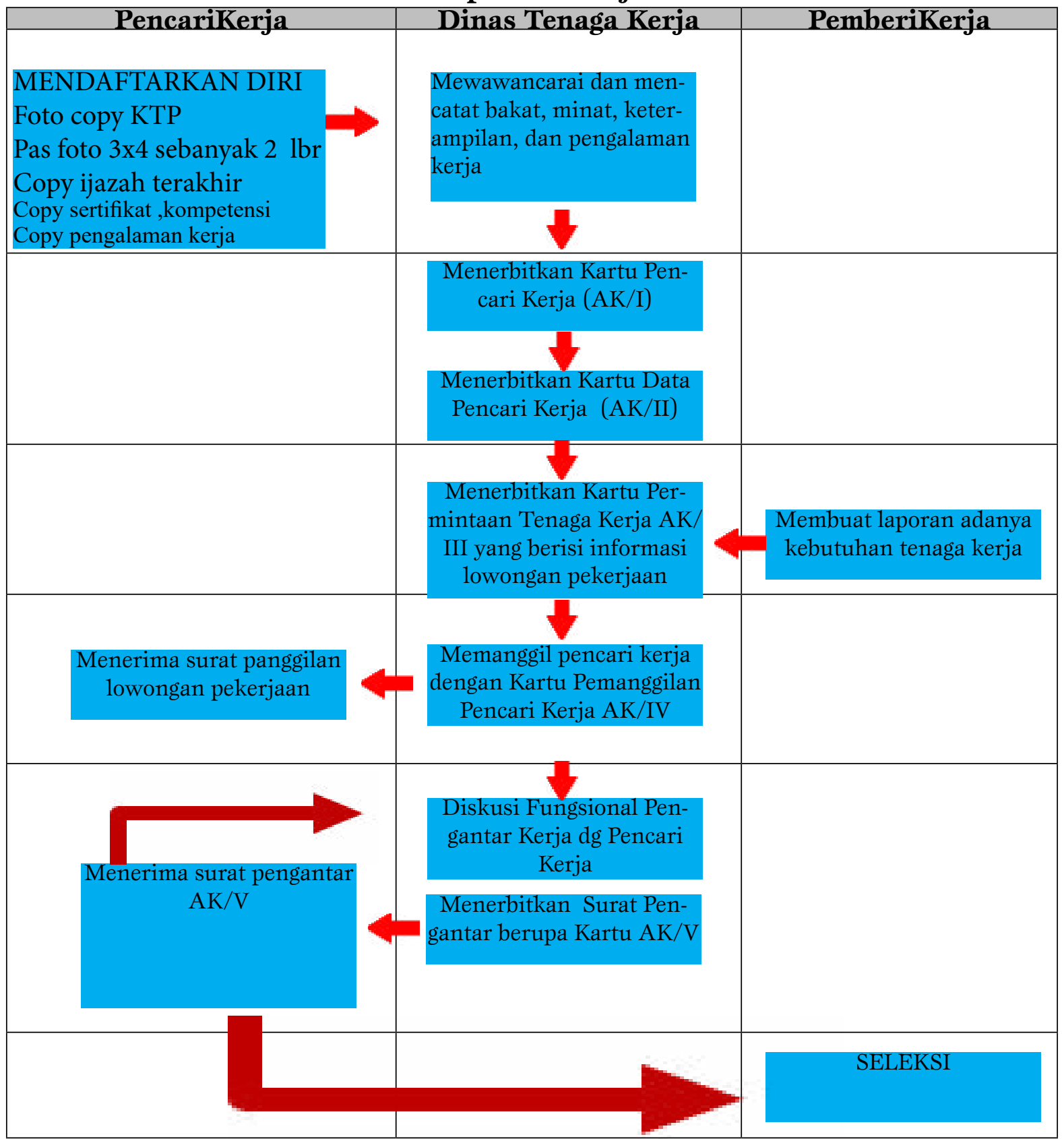

(Sumber: Permenaker No.39 tahun 2016 tentang Penempatan Tenaga Kerja) 
Pelaksanaan layanan penempatan tenaga kerja di Kota Malang sama dengan yang alur yang terdapat dalam Permenaker, yaitu mulai dari melakukan pendaftaran, pencatatan, dan wawancara bakat, minat dari pencari kerja. Prakteknya hanya sebagian kecil pencari kerja yang mendaftarkan diri untuk mendapatkan kartu pencari kerja atau yang dalam masyarakat dikenal dengan kartu kuning.

Disnaker Kota Malang memiliki2 (dua) tenaga fungsional Pengantar Kerja sebagaimana yang diamanatkan oleh Permenaker No.39 tahun 2016 yang bertugas untukmemberikan layanan pada pencari kerja mulai dari wawancara untuk menggali bakat dan minat atau konseling sampai dengan penempatan tenaga kerja jika ada informasi lowongan. Pegawai tersebut juga akan mengantarkan pencari kerja keperusahaan yang membutuhkan tenaga kerja. Bahkan tenaga fungsional tersebut juga merekomendasikan pencari kerja untuk mengikuti suatu latihan kerja jika dianggap belum memiliki keterampilan atau keahlian yang dibutuhkan oleh dunia kerja atau perusahaan.

Layanan penempatan tenaga kerja ini akan berjalan dengan baik jika pihak pencari kerja aktif untuk mendatangi dan berkonsultasi. Pihak Disnaker akan memberikanlayanan jika ada pendaftaran dari pihak pencari kerja. Dengan demikian pihak Disnaker akan melakukan aktivitas wawancara, memanggil untuk memberikan informasi tentang adanya lowongan pekerjaan jika ada keaktivan dari pihak pencari kerja. Format kartu yang diterbitkan dalam rangka penempatan tenaga kerja masih menggunakan model yang diatur dalam Permenakertrans No. 8 tahun 2008 yang secara prinsip sama.

Pihak yang terlibat dalam penempatan tenaga kerja menurut Permenaker 39 tahun 2016 adalah pencari kerja, tenaga fungsional pengantar kerja (pusat, provinsi, kota/ kabupaten), pemberikerja, LPTKS, dan BKK. Pencari kerja yang mendaftarkan diri ke Disnaker untuk mendapatkan pekerjaan tidak terlalu banyak, kebanyakan pencari kerja akan mendatangi Disnaker untuk mendapatkan kartu pencari kerja jika perusahaan atau instansi yang dituju untuk mendapatkan pekerjaan meminta kartu tersebut sebagai salah satu persyaratan untuk pendaftaran.

Pencari kerja memperoleh informasi lowongan pekerjaan dengan mendatangi job fair atau pameran bursa kerja yang diadakan oleh pihak kampus, Disnaker atau pihak swasta. Brosur-brosur yang disebarkan oleh perusahaan sering kali memberikanbatasan yang dapat membatasi kesempatan pencari kerja untuk memperoleh pekerjaan, misalnya batasan usia atau jenis kelamin ${ }^{22}$. Selain itu pencari kerja juga memperoleh informasi tentang adanya lowongan melalui media surat kabar, baik cetak maupun online. Informasi lowongan pekerjaan sangat penting bagi pencari kerja dan dapat menjadi alat yang sangat efektif di pasar tenaga kerja ${ }^{23}$. Beberapa kelemahan lowongan pekerjaan melalui media social yang dapat menjangkau atau diakses semua orang terkadang kurang efektif dalam menjaring pekerjaan, khususnya dari sisi pengusaha/pemberi kerja yaitu banyaknya pelamar yang tidak sesuai dengan persyaratan perusahaan ${ }^{24}$.

Disnaker yang berperan dalam memberikan layanan penempatan tenaga kerja melakukan pendaftaran, konseling, dan menyalurkan tenaga kerja yang mendafatarkan keperusahaan yang membutuhkan. Selainitu juga menyalurkan calon tenaga kerja pada

\footnotetext{
${ }^{22}$ Siti Awaliyah, The Effectiveness of Anti-Discrimination Laws for Job Seekers in Indonesia, Journal of Law, Policy and Globalization. Vol 51, 2016, Hal.51, 41.

${ }^{23}$ Steffen Altmann, Armin Falk, Simon Jager, Florian Zimmermann, Learning About Job Search: A Field Experiment with Job Seekers in Germany, Journal of Public Economics, Volume 164. Agustus 2018. Hal.33

24 Yulei Weng dan Hao Xu, How Guanxi Affects Job SeraccOutcames in China? Job Match and Job Turnover. Journal of China Economic Review, Volume 51 Oktober 2018, Hal.70.
} 
pusat-pusat pelatihan yang diharapkan akan sesuai dengan kebutuhan di lapangan atau dunia kerja.

Di Jawa Timur LPTKS sebagai lembaga swasta yang turut serta berperan dalam penempatan tenaga kerja terdapat di 7 (tujuh) kota dengan 17 lembaga yang berbentuk Perseroan Terbatas. Salah satu LPTKS yang berada di Kota Malang adalahPT. Rajawali Security Service. Perusahaan tersebut tercatat sebagai LPTKS yang telah memiliki surat ijin pendirian untuk melakukan layanan penempatan tenaga kerja. Perusahaan tersebut dalam daftar perusahaan di Disnaker kota Malang tercatat sebagai perusahaan jasa outsourcing.

Bursa KerjaKhusus (BKK) di Kota Malang saat ini cukup banyak yaitu berada di Sekolah Menengah Kejuruan (SMK) yang saat ini terdapat kurang lebih 18 BKK. SMK di kota Malang, baik negeri atau swasta hampir semuanya telah memiliki BKK yang memberikan layanan penempatan tenaga kerja bagi para alumninya. Beberapa perguruan tinggi juga memiliki BKK yang dapat menyalurkan para alumninya untuk mendapat kan pekerjaan, diantaranya UniversitasBrawijaya.

Pameran bursa kerja atau job fair dapat diselenggarakan oleh Disnaker, LPTKS, maupun BKK. Job fair seringkali dilakukan oleh perguruan tinggi, diantaranya yang setiap tahun mengadakan job fair dengan pengunjung yang banyak adalah Universitas Negeri Malang, Universitas Brawijaya, UIN Maliki, dan Politeknik Malang. Beberapa tahun lalu pelaksanaan job fair menarik biaya bagi pengunjung sekitar Rp 20.000,00. Hal tersebut bertentangan dengan peraturan penempatan tenaga kerja baik yang lama maupun yang baru yaitu larangan bagi penyelenggara job fair atau pameran bursa kerja untuk menarik biaya kepada pencari kerja. Penyelenggara pameran harus mendapatkan ijin dari Disnaker, akan tetapi seringkali juga pihak penyelenggara tidak membuat surat ijin untuk pelaksanaan kegiatan. Pihak Disnaker juga sudah melakukan penertiban terhadap hal tersebut sehingga untuk saat ini tidak ada penarikan biaya bagi pengunjung.

Job Fair yang penyelenggaraannya dilaksanakan bekerjasama atau dengan ijin Disnaker menjadi lebih efektif berkaitan dengan pendataan penempatan tenaga kerja. Saat ini dalam job fair sudah dilengkapi dengan wawancara langsung dengan perusahaan. Beberapa perusahaan telah menempatkan Human Resource Development (HRD) pada job fair tersebut. Kegiatan juga lebih efektif dengan adanya stand khusus yang dibuka oleh Disnaker untuk pendaftaran memperoleh kartu AK/I (kartu kuning) sehingga pencari kerja yang belum memperoleh pekerjaan dan belum memiliki kartu AK/I dapat mendaftarkan diri.

Permasalahan yang dihadapi pihak Disnaker berkaitan dengan penempatan tenaga kerja adalah dana untuk operasional penempatan tenaga kerja ke perusahaan. Pihak Disnaker berharap dapat mencarikan tenaga kerja ke perusahaan yang membutuhkan. Hal tersebut sebenarnya kurang sesuai dengan langkah-langkah yang seharusnya dilakukan dalam penempatan tenaga kerja. Pemberi kerja atau perusahaan seharusnya melaporkan tentang adanya kebutuhan atau lowongan pekerjaan diperusahaannya kepada Disnaker sehingga Disnaker tidak perlu mendatangi perusahaan. Laporan yang masuk ke Disnaker dicocokkan dengan daftar pencari kerja yang sudah mendaftarkan diri sebagai pencari kerja. Pemanggilan terhadap pencari kerja dengan kartu AK/IV sudah tidak digunakan karena pemanggilan cukup dengan menggunakan Whats App (WA).

Petugas Disnaker bagian penempatan tenaga kerja cukup bagus dalam hal sebagai penghubung dengan pemberi kerja yaitu dengan mengantarkan rombongan pencari kerja ke perusahaan yang membutuhkan sehingga Disnaker dapat mengetahui secara 
langsung kelebihan dan kelemahan dari pencari kerja. Kegiatan tersebut tidak diatur dalam peraturan sehingga dalam pelaksanaannya tidak ada penganggaran dana untuk kegiatan operaional tersebut.

\section{SIMPULAN}

Penempatan tenaga kerja menurut Undang-Undang No.39 tahun 2016 dilaksanakan melalui tahapan: (1) pendaftaran pencari kerja di Disnaker untuk memperoleh kartu pencari kerja AK/I, (2) data pencari kerja disimpan di Disnaker dalam AK/II, (3) perusahaan mengirimkan laporan kebutuhan tenaga kerja atau lowongan pekerjaan ke Disnaker dengan kartu AK/III, (4) Disnaker menerbitkan kartu AK/IV pemanggilan kepada pencari kerja setelah mencocokkan kualifikasi pencari kerja dalam kartu AK/II dengan kebutuhan perusahaan yang terdapat dalam AK/III, (5) Disnaker menerbitkan kartu pengantar $\mathrm{AK} / \mathrm{V}$ setelah melakukan diskusi dengan pencari kerja berkaitan dengan lowongan pekerjaan yang ada. Mekanisme penempatan tenaga kerja di Kota Malang dilaksanakan melalui tahap-tahap berikut: (1) pendaftaran yang dilakukan oleh pencari kerja ke Disnaker untuk memperoleh AK/I, (2) Disnaker mewawancarai dan menyimpan hasil wawancara dalam kartu AK/II, (3) Disnaker mencarikan lowongan pekerjaan melalui info-info selebaran yang diberikan oleh perusahaan atau mendatangi langsung perusahaan, (4) Disnaker memanggil pencari kerja melalui WA untuk datang ke Disnaker dan mendiskusikan adanya lowongan pekerjaan, (5) Disnaker menerbitkan kartu pengantar kerja $\mathrm{AK} / \mathrm{V}$ dan mengantarkan rombongan pencari kerja ke perusahaan yang membuka lowongan pekerjaan.

Disnaker Kota Malang memiliki 2 (dua) fungsional pengantar kerja yang bertugas memberikan layanan dalam penempatan tenaga kerja. Mekanisme penempatan tenaga kerja di Kota Malang secara umum sudah sesuai dengan ketentuan dalam Permenaker No.39 tahun 2016, mulai dari pendaftaran dan penerbitan kartu pencari kerja AK/I ke Disnaker, wawancara dan pendataan kualifikasi pencari kerja dalam kartu AK/ II. Pemberi kerja/perusahaan tidak memiliki kewajiban untuk melaporkan lowongan pekerjaan yang terdapat di perusahaan, pemberitahuan perusahaan seringkali berupa brosur atau selebaran tentang adanya lowongan. Disnaker mencocokkan lowongan pekerjaan dengan kualifikasi data pencari kerja dan memanggil pencari kerja menggunakan media sosial. Disnaker mengantarkan pencari kerja ke perusahaan. Prosedur penempatan tenaga kerja kurang efektif karenatidak ada kewajiban pemberi kerja untuk melaporkan setiap kebutuhan tenaga kerja di perusahaannya ke Disnaker. Hal tersebut menyebabkan Disnaker tidak dapat menjadi penghubung secara maksimal antara pencari kerja dengan pemberi kerja sesuai peraturan.

\section{DAFTAR PUSTAKA}

\section{Buku}

Budiono, Abdul Rachmad. (2011). Hukum Perburuhan. PT. Indeks:Jakarta.

Bungin, Burhan. (2015). Analisis DataPenelitianKualitatif.PT.Raja GrafindoPersada. Jakarta.

Kusuma, Candra. (2013). Penelitian Interdisipliner Tentang Hukum. Epistema Institute. Jakarta.

Pusat Data dan Informasi Ketenagakerjaan Badan Penelitian, Pengembangan dan Informasi. (2013). Karakteristik Ketenagakerjaan Umum Kabupaten/Kota 
di Indonesia Tahun 2012. Kementerian Tenaga Kerja dan Transmigrasi RI. Jakarta.

Rusli, Hardijan. (2011). Hukum Ketenagakerjaan, Berdasarkan UU No.13 No. 13/2003 tentang Ketenagakerjaan dan Peraturan Terkait Lainnya. Ghalia Indonesia. Bogor.

Sub Direktorat Klasifikasi dan Pembakuan Statistik Derektorat Metodologi Statistik. (2002). KBJI 2002, Klarifikasi Baku Jenis Pekerjaan Indonesia. Badan Pusat Statistik. Jakarta.

Sutedi, Adrian. (2009). Hukum Perburuhan. PT. Sinar Grafika. Jakarta.

Jurnal dan Karya Ilmiah Lain

Altmann, S., Falk, A., Jäger, S., \& Zimmermann, F. (2018). Learning about job search: A field experiment with job seekers in Germany. Journal of Public Economics, 164, 33-49.

Awaliyah, S. (2016). The Effectiveness of Anti-Discrimination Laws for Job Seekers in Indonesia. JL Pol'y \& Globalization, 51, 41.

Blázquez, M., Herrarte, A., \& Sáez, F. (2019). Training and job search assistance programmes in Spain: The case of long-term unemployed. Journal of Policy Modeling, 41(2), 316-335.

Weng, Yulei dan Hao Xu. 2018. How Guanxi Affects Job SeraccOutcames in China? Job Match andJob Turnover. Journal China Economic Review. Volume 51.Oktober 2018. Hal.70.

\section{PeraturanPerundang-Undangan}

Republik Indonesia. Peraturan Menteri Ketenagakerjaan Republik Indonesia Nomor 39 Tahun 2016 Tentang Penempatan Tenaga Kerja (Berita Negara Republik Indonesia Tahun 2016 Nomor 1990)

\section{Website}

Badan Pusat Statistik. 2017. Pengangguran Terbuka Menurut Pendidkan Tertinggi yang Ditamatkan 1986-2016. Online. https://www.bps.go.id/linkTabelStatis/ view/id/972. Diakses tanggal 12 Januari 2017.

Iqbal. 2016. Alamak, 29.606 Pengangguran ada di Kota Malang. Jawa Pos Radar Malang Online. http://radarmalang.co.id/alamak-29-6060-pengangguran-adadi-kota-malang-41627.htm. Diakses tanggal 24 Januari 2017 